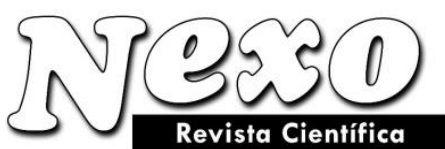

Vol. 34, No. 04, pp. 1515-1520/Septiembre 2021
ISSN-E 1995-9516

Universidad Nacional de Ingeniería COPYRIGHT @ (UNI). TODOS LOS DERECHOS RESERVADOS http://revistas.uni.edu.ni/index.php/Nexo https://doi.org/10.5377/nexo.v34i04.12697

\title{
High frequency power supply to improve operation stability of linear electron accelerator
}

\section{Alimentación de alta frecuencia para mejorar la estabilidad de funcionamiento del acelerador de electrón lineal}

\author{
Vladimir Kuzmich Shilov", Aleksandr Nikolaevich Filatov, Aleksandr Evgenevich Novozhilov \\ National Research Nuclear University MEPhI (Moscow Engineering Physics Institute), Moscow, 115409, \\ Russian Federation \\ * shilov_v.k@mail.ru
}

(recibido/received: 28-mayo-2021; aceptado/accepted: 13-julio-2021)

\begin{abstract}
The use of linear electron accelerators in medicine and industry is explained by the simplicity of the input and output of accelerated electrons and adjusting the energy and dose rate, as well as the high dose rate of bremsstrahlung. The purpose of this work is to increase the stability of their work. A standing wave accelerator containing a high-frequency generator, a phase shifter, a waveguide bridge, a high-frequency load, and an accelerating system of two accelerating sections is equipped with two waveguide tees. Their inputs are connected to the output arms of the waveguide bridge, and the first and second output arms of each tee are connected to the first and last accelerating cells of each section, respectively. In this system, due to the introduction of several elements that do not require large costs for manufacturing and tuning, a significantly greater frequency separation of the operating mode of oscillations from neighboring ones is ensured, or even a single-frequency excitation mode is implemented, which makes it possible to significantly increase the stability of the accelerator operation. This technique can be used to increase the stability of operation in the design and calculation of linear accelerators of electrons with a standing wave.
\end{abstract}

Keywords: Linear Electron Accelerator; Biperiodic Slowing System; Standing Wave; Phase Shifter; Generator; T-Junction; Waveguide Bridge.

\section{RESUMEN}

El uso de aceleradores de electrones lineales en la medicina y la industria se explica por la simplicidad de la entrada y salida de electrones acelerados y el ajuste de la energía y la tasa de dosis, así como la alta tasa de dosis de bremsstrahlung. El propósito de este trabajo es aumentar la estabilidad de su trabajo. Un acelerador de ondas estacionarias que contiene un generador de alta frecuencia, un desfasador, un puente de guía de ondas, una carga de alta frecuencia y un sistema de aceleración de dos secciones de aceleración está equipado con dos tes de guía de ondas. Sus entradas están conectadas a los brazos de salida del puente de la guía de ondas, y el primer y segundo brazos de salida de cada T están conectados a la primera y última celda de aceleración de cada sección, respectivamente. En este sistema, debido a la introducción de varios elementos que no requieren grandes costos de fabricación y sintonización, se asegura una separación de frecuencia significativamente mayor del modo de funcionamiento de las oscilaciones de las vecinas, o incluso se implementa un modo de excitación de frecuencia única, lo que permite aumentar significativamente la estabilidad del funcionamiento del acelerador. Esta técnica se puede utilizar para 
aumentar la estabilidad de funcionamiento en el diseño y cálculo de aceleradores lineales de electrones con onda estacionaria.

Palabras claves: Acelerador lineal de electrones; Sistema de ralentización biperiódica; Onda estacionaria; Desplazador de fase; Generador; Unión en T; Puente de guía de ondas.

\section{INTRODUCTION}

Application of linacs in medicine and industry is attributed to their numerous advantages: simplicity of input and output of accelerated electrons, simplicity of adjustment of dose energy and rate, high dose rate of braking radiation even at comparatively moderate energies of accelerated particles.

Intensive development of accelerators for fundamental studies in the field of high energy physics and significant research advances in other fields provide possibility of practical use of accelerators in industry (Novozhilov, 2016), medicine (Auditore et al., 2006), and environmental protection (Vakhrushin et al., 1995).

In the energy range of 2-50 MeV, travelling wave accelerators are mostly used. However, when a compact accelerator is required, the standing wave accelerator is more preferred. Linac operation modes are compared in (Zavadtsev, 1994), reasonability of standing wave accelerators for low and medium energies is demonstrated.

Biperiodic decelerating structure (BDS) in standing wave linac can be considered as a chain of accelerating resonators located on one axis and interconnected by coupling cells (Novozhilov, Filatov, Shilov, 2016a; 2016b). Since the coupling cells are free from electromagnetic fields, then they can be located beyond the accelerating structure. An electron travels the distance between the centers of adjacent resonators in half the period of electromagnetic oscillations (equal to 0.5 \pi), since oscillations of electromagnetic fields in adjacent accelerating resonators differ in phase by \pi. Thus, the synchronization of the electron and the accelerating field is obtained.

If the function of distribution of electric field intensity along the axis of standing wave linac is considered at certain time, then it can be seen that it is comprised of alternated pulses of different polarity with spatial period equaling to the generator wavelength (Novozhilov, Filatov, Shilov, 2015). The most promising in standing wave linac is focusing upon which beam transmission is based on focusing action of the electromagnetic field itself (Fainberg, 1962). As mentioned above, this becomes possible due to occurrence of radial component of electric field in BDS cells (Novozhilov, Filatov, Shilov, 2017).

Application of focusing properties of BDS HF eigenfields reduces significantly transversal dimensions of accelerating section as well as total weight of accelerator. In addition, no huge power sources are required for external focusing devices adding difficulties in operation of accelerators, which is especially important in geology, medicine, and nondestructive testing.

Power supply of linac accelerating sections from magnetron via waveguide bridge in terms of such performances as efficiency, sizes and manufacturability, cost of main and auxiliary equipment is more preferable in comparison with other variants of power supply (Kalyuzhnyi, 2013). If the characteristics of the bridge are chosen correctly, the frequency of the magnetron will be stabilized by a factor of ten or more. A schematic diagram of a linear electron accelerator powered through a waveguide bridge can be seen in Figure 1. 


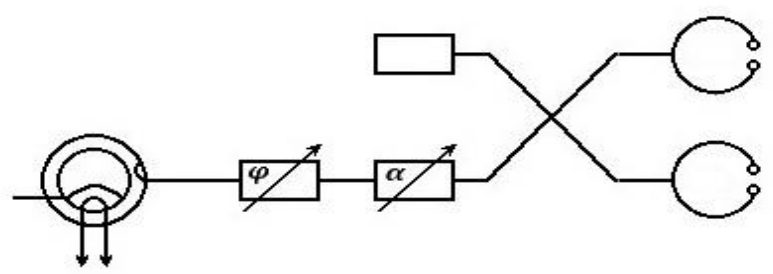

Figure 1. Scheme of power supply of the linear electron accelerator through the waveguide bridge

In Figure 1, two accelerating sections are connected to the output arms of the waveguide bridge. It, in turn, provides decoupling of the magnetron from the high-Q load. The energy reflected from the section during the transient process enters the waveguide absorbing load, and its level is regulated with the help of an attenuator, thereby regulating the input energy of the LEA electrons.

Currently, there are many designs of attenuators operating at high energy levels (Helszajn, 1978). A.E. Novozhilov in his work (2014) presented a compact, simple, and easy-to-use adsorption-type attenuator, which is a segment of a rectangular waveguide. Two low-quality tunable prismatic resonators covered with sendust are connected to its wall, separated from each other by $\frac{3}{4} \lambda_{v}$ where $\lambda_{v}$ is the wavelength in the waveguide. The connection of these resonators with the waveguide is carried out through the holes in the wall of the waveguide, and the restructuring occurs with the help of throttle pistons. This attenuator regulates the transmitted energy, but at the same time absorbs part of it even with a strong detuning of the resonators. Therefore, it is impossible to fully match the attenuator with the RF path over the entire range of regulated energy.

\section{METHODS}

This is a standing wave accelerator containing a HF generator, a phase shifter, a waveguide bridge, a HF load, an accelerating system comprised of two accelerating sections, accelerating cells and coupling cells positioned alternately along the linac axis. Aiming at improvement of operation stability of linac, two waveguide T-junctions are added with their inputs connected to output ports of waveguide bridge, the first and the second output ports of each T-junction are connected with the first and the last accelerating cells of each section, respectively; the coefficient of coupling of each accelerating section with the output port of T-junction is $\beta \geq \frac{1}{2}$, and the cumulative electric length of the first and the second output ports of each waveguide T-junction is $l=\frac{1}{4}(2 N+1) \lambda_{v}$, where $N$ is the number of accelerating cells of each section; $\lambda_{v}$ is the wavelength in waveguide during working oscillations.

The proposed circuit is a small-sized standing wave linac intended for application in various fields, for instance, for nondestructive testing, in radiation chemistry and medicine. There are known standing wave accelerators, their accelerating system is comprised of two accelerating sections powered from magnetron via waveguide bridge (Zverev, 1981). Each section is comprised of cells of two types: accelerating and coupling, and is excited at $\frac{\pi}{2}$ oscillations.

The closest in technical essence to the proposed engineering solution is a standing wave linac comprised of a HF generator, a phase shifter, a waveguide bridge, HF loads, and an accelerating system of two accelerating sections, the accelerating cells and coupling cells of which are positioned alternately along the linac axis (Vaguine, 1977). A drawback of this prototype is low frequency diversity of oscillation types in such system with significant number of accelerating cells, which can lead to unsteady operation of generator and overall accelerator. 
This system is aimed at improvement of operation stability of accelerator, which is achieved as follows: the standing wave linac comprised of a HF generator, a phase shifter, a waveguide bridge, HF loads, and an accelerating system of two accelerating sections, the accelerating cells and coupling cells of which are positioned alternately along the linac axis, is supplemented by two waveguide T-junctions, their inputs connected to output ports of waveguide bridge, the first and the second output ports of each T-junction are connected with the first and the last accelerating cells of each section, respectively; the coefficient of coupling of each accelerating section with the output port of $\mathrm{T}$-junction is $\beta \geq \frac{1}{2}$, and the cumulative electric length of the first and the second output ports of each waveguide T-junction is $l=\frac{1}{4}(2 N+1) \lambda_{v}$, where $N$ is the number of accelerating cells of each section, $\lambda_{v}$ is the wavelength in waveguide during working oscillations.

\section{RESULTS AND DISCUSSION}

Figure 2 illustrates the standing wave accelerator with the proposed HF power supply circuit. It is comprised of the first accelerating section comprised of the accelerating cells 1 and the coupling cells 2, and the second accelerating section comprised of the accelerating cells 3 and the coupling cells 4 . In addition, it is comprised of the two waveguide T-junctions 5 and 6 connected to the bridge ports 7 , HF load 8, the phase shifter 9 and the HF generator (magnetron) 10.

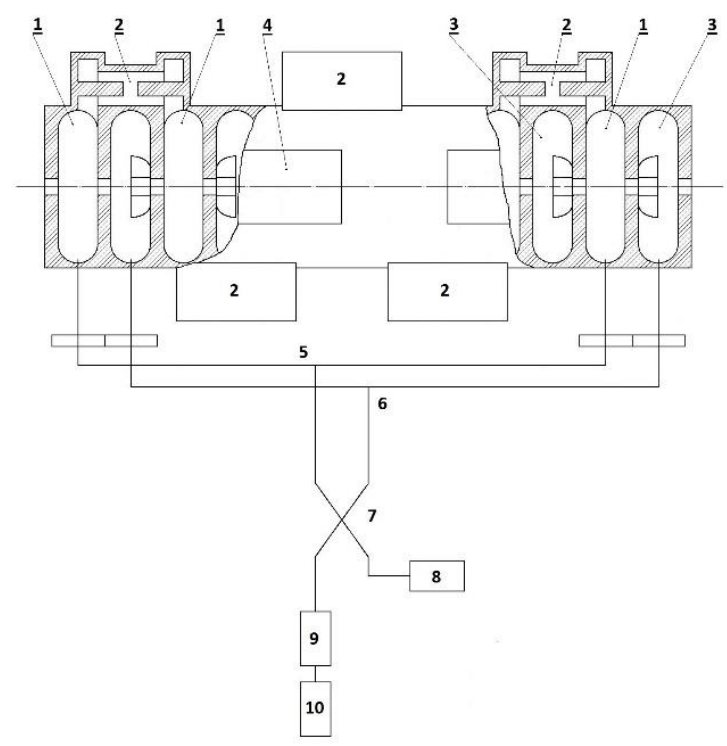

Figure 1. Linac with proposed HF power supply via waveguide bridge.

The system operates as follows: HF energy from the generator 10 passes through the phase shifter 9 and is subdivided in two halves by the bridge 7 , then each half, in its turn, is subdivided in two halves in the Tjunctions 5, 6 and supplied to the first and the last cells of the first and the second section, respectively. Herewith, if the number of accelerating cells of each section $\mathrm{N}$ is even, then the T-junctions 5, 6 are of $E$ type, if $N$ is odd, then they are of $H$ - type. If the lengths of the first and the second port of each T-junction are equal, and the coefficients of coupling of all waveguides and sections are $\frac{1}{2}$, then in the steady mode all energy will be supplied to the accelerating sections, which will be excited at $\frac{\pi}{2}$ working oscillations.

Herewith, in the case of even $N$ instead of (2N-1) resonant frequencies of HF field, the excitation of $N$ type oscillations is possible, and if $N$ is odd, then instead of $(2 N-1)$, the $(N-1)$ resonant frequencies will 
take place. Therefore, partial subdivision of oscillation types increases by two times. If the cumulative length of the first and the second port of each T-junction 5,6 is $l=\frac{1}{4}(2 N+1) \lambda_{v}$, where $\lambda_{v}$ is the wavelength at working type of oscillations, and the port lengths are different, then such system should be considered as a closed-loop system.

For the closed-loop system, the condition of oscillation excitation is $\sum_{k} \varphi_{k}=2 \pi n$, where $\varphi_{k}$ is the phase shift in the k-th element of closed-loop chain. In this case, excitation of only one type of working oscillations is possible, since the change of phase shift in waveguides will be as follows:

$$
\Delta \varphi=\frac{f_{n}}{f_{0}} \sqrt{\frac{4 a^{2} f_{0}^{2}-c^{2}}{4 a^{2} f_{n}^{2}-c^{2}}}(2 N+1) \pi / 2,
$$

where $f_{0}$ is the frequency of working oscillations, $f_{n}$ is the frequency of other oscillations, $a$ is the diameter of accelerating cell, $c$ is the speed of light; hence, it may turn out that the condition of excitation is not satisfied at any $n$.

In the case of significant number of accelerating cells, other types of oscillations can be excited, the frequency diversity from the neighboring types will be rather high all the same. In this case, a portion of energy in steady mode will be returned back to the HF bridge 7, and it can be used for stabilization of the frequency of the magnetron 10 by high-Q load - the resonator sections.

In transient mode, the HF energy reflected from the sections is supplied to the load 8 and is dissipated there. It would be reasonable to apply the waveguide bridge 7 with coupling across wide wall in the case of $E$ - T-junctions 5 and 6 . Therefore, in this system, due to addition of several elements not requiring for high costs of manufacture and tuning, significantly higher frequency separation of working oscillations from neighboring ones is provided or even single frequency mode of excitation is achieved, thus allowing to improve significantly the operation stability of accelerator.

\section{CONCLUSIONS}

The paper considered the possibility of the existence of a design of a modified accelerating structure with a standing (biperiodic) wave and an electromagnetic supply circuit to increase the efficiency of electron acceleration in linear accelerators. Thus, in the accelerating resonator sections of the multisection accelerator, a deep control of the high-frequency energy level was realized.

In the power supply circuit of the linear electron accelerator through the waveguide bridge, the magnetron is completely decoupled from the high-Q accelerating sections. This led to an improvement in the output characteristics of the electron beam at the exit of the accelerator, as well as a decrease in the effect of the current loading of the accelerating sections.

This technique can be used in the design and calculation of linear accelerators of electrons with a standing wave.

\section{ACKNOWLEDGEMENTS}

This work was supported by MEPhI Academic Excellence Project (contract No. 02.a03.21.0005, 27.08.2013). 


\section{REFERENCIAS}

Auditore, L., Barna, R.C., De Pasquale, D., Emanuele, U., Trifiro, A., \& Trimarchi, M. (2006). A Compact $5 \mathrm{MeV}$, S-Band, Electron Linac Based X-Ray Tomography System. In 10th European Particle Accelerator Conference, Edinburgh.

Fainberg, Ya.B. (1962). O vozmozhnosti odnovremennoy radial'noy i fazovoy ustoychivosti v lineynykh uskoritelyakh bez spetsial'nykh fokusiruyushchikh ustroystv [On the Possibility of Simultaneous Radial and Phase Stability in Linear Accelerators without Special Focusing Devices]. In Teoriya i raschet lineynykh uskoriteley [Theory and Calculation of Linear Accelerators]. Moscow: Gosatomizdat.

Helszajn, J. (1978). Passive and Active Microwave Circuits. New York: John Wiley \& Sons.

Kalyuzhnyi, V.E. (2013). Relative Jitter of Accelerating Voltage Amplitude on Resonator's Cells of Linear Electron-positron collider TESLA-ILC. World Applied Sciences Journal, 27(12), 1620-1624.

Novozhilov, A. E. (2014). Assessment of method errors in measurement of acceleration fields in accelerating sections of charged particle accelerators. Life Science Journal, 11(11s), 506-510.

Novozhilov, A.E. (2016). Modified Biperiodic Structures for Linear Particle Accelerators. International Journal of Advanced Trends in Computer Science and Engineering, 8(6), pp. 3535 - 3539.

Novozhilov, A.E., Filatov, A.N., Shilov, V.K. (2015). Problems of Beam Focusing by Electromagnetic Field in Linear Electron Accelerator with Standing Wave, Based on Biperiodic Structure. Modern Applied Science, 9(4), 160-169.

Novozhilov, A.E., Filatov, A.N., Shilov, V.K. (2016a). Problems of measurement of high-frequency fields in linear electron accelerators. Global Journal of Pure and Applied Mathematics, 12(1), 643-655.

Novozhilov, A.E., Filatov, A.N., Shilov, V.K. (2016b). Distribution of Accelerating Voltage in Resonator of Linear Electron-Positron Collider. International Journal of Applied Engineering Research, 11(3), 15961602.

Novozhilov, A.E., Filatov, A.N., Shilov, V.K. (2017). Calculation of bunchers in linear electron accelerators with standing wave. ARPN Journal of Engineering and Applied Sciences, 12(1), 182-187.

Vaguine, V.A. (1977). Standing wave high gradient accelerator structure. Review of Scientific Instruments, 48(12), 1658-1660.

Vakhrushin, Y., Vyaz'mentzova, G., Kuznetzov, V., \& Fidel'skaya, R. (1995). Dezinfektsiya stochnykh vod infektsionnykh bol'nits elektronnym puchkom [Sewage water disinfection in infectious hospitals by electron beam], In: Proceedings, Accelerators-95, Meeting devoted to application of particle accelerators in industry and medicine, Saint-Petersburg.

Zavadtsev, A. (1994). Biperiodic U-structures for Particle Accelerators. Fourth European Accelerator Conference, vol. 3, pp. 2176-2178. London.

Zverev, B.V. (1981). Raschet i proektirovanie malogabaritnogo uskoritelya elektronov RELUS-3 [Development of RELUS-3 small-scale electron accelerator]. In: Accelerators, issue 20. Moscow: Energoizdat. 